\title{
Identifikasi Indikator Kemampuan Komunikasi Matematis pada Soal USBN Matematika SD/MI Tahun Ajaran 2018/2019
}

\author{
Erma Wahyu Hutami ${ }^{1}$, Layli Umaya Sari ${ }^{2}$, Ririn Nur Vitasari ${ }^{3}$, Bintang Wicaksono ${ }^{4}$ \\ Program Studi Pendidikan Matematika, Universitas PGRI Yogyakarta. Jalan PGRI 1. Sonosewu No.117 \\ Kota Yogyakarta, Indonesia. \\ ermautami666@gmail.com ${ }^{1}, \underline{\text { mayalayli.97@gmail.com² }}$, dekri2n@gmail.com ${ }^{3}$, bintang@upy.ac.id ${ }^{4}$
}

\begin{abstract}
Mathematic communication skills is one of the critical indicator in learning and evaluation of mathematic lesson. But in reality, not all tests accepted by students can upgrade their mathematic communication skills. Meanwhile based on Regulation from National Education Minister Number 22 Year of 2006 it is mentioned that one of the goals of mathematic learning is for students have capability to communicate ideas with symbols, tables, charts, and any other media to clarify the conditions or problems. Based on that it is necessary to identify mathematic communication skills indicator on mathematic tests. Moreover on the mathematic USBN, where the results determine the students's final score. The mathematic communication skills indicator which would be identified were: 1) connects the real things, picture and charts to the mathematic ideas, 2) explains ideas, situations and mathematic relations with speech or texts with real things, pictures, graphs and algebra, 3) listens, discusses and writes about mathematics, 4) states daily activity in mathematic languace, 5) reads with understanding about written mathematic presentation, 6) makes mathematic statement which is relevant with problem situation, and 7) makes conjectures, arguments, determines definition and generalisation. In here the mathematic communication skills that would be analyzed was students capability to solve contextual problems. On Mathematic USBN for Elementary School in the year 2018/2019 there were 35 problems, where 30 problems were multiple choice and 5 were essay. There were few problems contains mathematic communication skills indicator which were number $31,32,33,34,35$.
\end{abstract}

Keywords: communication skills, Mathematic USBN for Elementary School in the year 2018/2019 Abstrak

Kemampuan komunikasi matematis merupakan salah satu hal yang harus diperhatikan dalam pembelajaran dan penilaian pada mata pelajaran matematika. Namun pada kenyataannya tidak semua soal yang diterima siswa mampu meningkatkan kemampuan komunikasi matematis siswa. Padahal berdasarkan pada Peraturan Mentrian Pendidikan Nasional No. 22 Tahun 2006 disebutkan bahwa salah satu tujuan pembelajaran matematika adalah supaya siswa memiliki kemampuan mengkomunikasikan gagasan dengan simbol, tabel, diagram, atau media lainnya untuk memperjelas keadaan atau masalah. Oleh karena itu perlu adanya identifikasi indikator kemampuan komunikasi matematis dalam soal-soal matematika. Terlebih lagi pada soal yang terdapat dalam USBN matematika, dimana hasil dari USBN tersebut menentukan nilai akhir siswa. Indikator kemampuan komunikasi matematis yang akan diidentifikasi antara lain: 1) menghubungkan benda nyata, gambar, dan diagram ke dalam ide matematika, 2) menjelaskan ide, situasi, dan relasi matematika secara lisan atau tulisan dengan benda nyata, gambar, grafik, dan aljabar, 3) mendengarkan, diskusi, dan menulis tentang matematika, 4) menyatakan peristiwa sehari-hari dalam bahasa matematika, 5) membaca dengan pemahaman suatu presentasi matematika tertulis, 6) menyusun pernyataan matematika yang relevan dengan situasi masalah, dan 7) membuat konjektur, menyusun argumen, merumuskan definisi dan generalisasi. Dalam hal ini kemampuan komunikasi matematis yang akan dianalisis adalah kemampuan siswa dalam menyelesaikan masalah kontekstual. Pada soal Ujian Sekolah Berstandar Nasional Matematika SD/MI Tahun Ajaran 2018/2019 terdapat 35 soal, di mana 30 soal merupakan soal pilihan ganda dan 5 soal merupakan soal essay. Terdapat beberapa butir soal yang memuat indikator kemampuan komunikasi matematis yaitu soal nomor 31,32,33,34,35.

Kata Kunci: Kemampuan komunikasi; soal USBN Matematika SD/MI Tahun Ajaran 2018/2019.

\section{PENDAHULUAN}

Pembelajaran di satuan pendidikan dasar saat ini sudah menggunakan kurikulum 2013

yang mempunyai karakteristik yaitu pembelajaran yang di dalamnya siswa harus berperan lebih aktif daripada kurikulum yang sebelumnya. Sebelumnya dengan kurikulum 2006 siswa cenderung kurang aktif dalam pembelajaran, karena kurikulum ini tidak mengharuskan untuk 
pembelajaran yang mengacu kepada keikutsertaan atau keaktifan siswa dalam pembelajaran. Siswa akan lebih mudah mengembangkan kemampuannya jika siswa berani untuk mengungkapkan pendapat atau hasil pemikirannya sendiri. Sehingga siswa akan lebih bersemangat dalam meningkatkan kemampuan komunikasinya.

Dalam matematika, komunikasi memegang peranan yang sangat penting. Melalui komunikasi siswa dapat mengembangkan berbagai ude-ide matematika atau membangun pengetahuannya. Komunikasi merupakan bentuk pesan atau lambang yang menimbulkan pengaruh pada proses umpan balik, sebab dengan adanya umpan balik sudah membuktikan adanya jaminan bahwa pesan telah tersampaikan kepada pendengar maupun pembaca. Komunikasi matematis adalah suatu keterampilan penting dalam matematika yaitu kemampuan untuk mengekpresikan ide-ide matematika secara koheren kepada teman, guru, dan lainnya melalui bahasa lisan maupu tulisan. Dengan menggunakan bahasa matematika yang benar untuk berbicara dan menulis tentang apa yang mereka kerjakan, mereka akan mampu mengklarifikasi ide-ide mereka dan belajar bagaimana membuat argument yang meyakinkan dan mempresentasikan ide-ide matematika.

Dengan kemampuan komunikasi matematis siswa dituntut untuk dapat menyampaikan gagasan/ide matematis, baik secara lisan maupun tulisan. Kemampuan komunikasi matematis ini dapat juga di lihat dari butir-butir soal USBN Matematika SD/MI Tahun Ajaran 2018/2019, dimana dari butir-butir soal tersebut dapat diidentifikasi indikator yang memuat kemampuan komunikasi matematis. Butir-butir soal USBN Matematika SD/MI Tahun Ajaran 2018/2019 yang diselesaikan oleh siswa memuat salah satu atau semua indikator kemampuan komunikasi matematis atau sebaliknya tidak memuat indikator kemampuan komunikasi matematis siswa sama sekali.

Soal USBN Matematika SD/MI Tahun Ajaran 2018/2019 memiliki tujuan untuk mengukur kompetensi lulusan pada setiap angkatannya. Soal ini berjumlah 35 soal, dimana 30 soal merupakan soal pilihan ganda dan 5 soal merupakan soal essay. Selain itu, soal-soal USBN Matematika SD/MI Tahun Ajaran 2018/2019 telah ditelaah dan diteliti oleh BNSP (Badan Nasional Standar Pendidikan). Sehingga dapat digunakan untuk penentu nilai akhir siswa yang bila hasilnya baik akan sangat memudahkan siswa untuk melanjutkan pendidikan ke jenjang yang lebih tinggi yaitu Sekolah Menengah. Dalam soal-soal tersebut dapat di identifikasi satu-satu apakah soal tersebut dapat dipecahkan dengan kemampuan komunikasi matematis siswa atau tidak.

\section{PEMBAHASAN}

\subsection{Tinjauan Umum Kemampuan Komunikasi Matematis}


Kemampuan komunikasi matematis merupakan kemampuan untuk menyampaikan gagasan/ide matematis. Komunikasi matematis merupakan salah satu aspek (kompetensi) yang harus dimiliki siswa dalam proses pembelajaran matematika. Karunia dan Mokhammad (2017:83) mengatakan bahwa kemampuan komunikasi adalah kemampuan menyampaikan gagasan/ide matematis, baik secara lisan maupun tulisan serta kemampuan memahami dan menerima gagasan/ide matematis orang lain secara cermat, analis, kritis, dan evaluatif untuk mempertajam pemahaman. Sedangkan Hodiyanto (2017) mengatakan bahwa kemampuan komunikasi matematis terdiri atas, komunikasi lisan dan komunikasi tulisan. Pengertian kemampuan komunikasi yang lain disampaikan juga oleh Yani Ramdani (2012) komunikasi matematis adalah kemampuan untuk berkomunikasi yang meliputi penggunaan keahlian menulis, menyimak, menelaah, menginterpretasikan, dan mengevaluasi ide, simbol,istilah, serta informasi matematika yang diamati melalui proses mendengarkan, mempresentasikan dan diskusi.

Selanjutnya Kurnia dan Mokhammad (2017:83) menjelaskan bahwa terdapat beberapa indikator kemampuan komunikasi matematis antara lain:

a. Menghubungkan benda nyata, gambar, dan diagram kedalam ide matematika.

b. Menjelaskan ide, situasi, dan relasi matematika secara lisan maupun tulisan, dengan benda nyata, gambar, garfik dan aljabar.

c. Menyatakan peristiwa sehari-hari dalam matematika.

d. Mendengarkan, diskusi, dan menulis tentang matematika.

e. Membaca dengan pemahaman suatu presentasi matematika tertulis.

f. Menyusun pertanyaan matematika yang relevan dengan situasi masalah.

g. Membuat konjektur, menyusun argumen, merumuskan definisi dan generalisasi.

Setelah mencermati beberapa pendapat di atas, dapat disimpulkan kemampuan komunikasi matematis adalah kemampuan yang sangat penting dalam pembelajaran matematika. Dalam hal ini, kemampuan komunikasi matematis yang akan dianalisis adalah kemampuan siswa dalam menyelesaikan masalah kontekstual karena dalam setiap masalah kontekstual dapat dianalisis kemampuan siswa dalam menghubungkan benda nyata ke dalam ide matematika, menjelaskan situasi matematika secara tertulis, menyatakan peristiwa seharihari dalam kalimat matematika, menyusun pertanyaan matematika, dan membuat generalisasi. Setelah dicermati secara rinci dari penjelasan Kurnia dan Mokhammad, indikator kemampuan komunikasi matematis yang akan dianalisis adalah: merumuskan informasi, menentukan strategi penyelesaian, menyelesaikan masalah, menjelaskan jawaban yang telah diperoleh (generalisasi). Dengan kemampuan komunikasi matematis siswa diharapkan mampu 
menjelaskan, menggambarkan, dan menyatakan, sehingga siswa mendapat pemahaman yang mendalam tentang matematika.

\subsection{Identifikasi kemampuan komunikasi matematis pada soal USBN SD/MI tahun ajaran 2018/2019}

Identifikasi kemampuan komunikasi matematis pada soal USBN SD/MI tahun ajaran 2018/2019 dilakukan untuk mengetahui adanya soal USBN yang memenuhi indikator kemampuan komunikasi matematis. Dalam soal tersebut terdapat beberapa soal yang dapat dilihat indikator kemampuan komunikasi matematis. Soal yang memenuhi indikator kemampuan komunikasi metematis terdapat pada soal essay. Dengan soal essay atau uraian siswa dapat mengembangkan analisa dan kemampuan komunikasi yang tidak hanya disempitkan pada pilihan jawaban yang tersedia. Hal tersebut juga justru membuat siswa dapat berpikir kreatif. Sedangkan pada soal pilihan ganda, dengan adanya pilihan jawaban berarti ada kesempatan untuk siswa mencoba keberuntungan dengan memilih salah satu dari pilihan yang ada, dan jika beruntung akan benar jawabannya. Soal pilihan ganda juga menyebabkan siswa tidak dapat berpikir dengan luas untuk mengembangkan pemikiran dan analisanya. Dalam hal ini, soal pilihan ganda tidak diidentifikasi kemampuan komunikasi matematis siswa karena tidak terdapat kesimpulan dari mana siswa memperoleh jawaban yang mereka pilih atau dengan kata lain bagaimana siswa memperoleh jawaban dari soal pilihan ganda tersebut. Sehingga, pada soal Ujian Sekolah Berstandar Nasional Matematika SD/MI Tahun Ajaran 2018/2019 terdapat 35 soal, di mana 30 soal merupakan soal pilihan ganda dan 5 soal merupakan soal essay, terdapat beberapa butir soal yang memuat indikator kemampuan komunikasi matematis yaitu soal nomor 31,32,33,34,35 dan diuraikan sebagai berikut.

Soal nomor 31

31. Seorang pengunjung sedang mengamati denah hutan wisata. la melihat jarak dari pintu masuk menuju tempat air terjun $6 \mathrm{~cm}$. Jika skala denah hutan wisata tersebut $1: 25,000$, berapa km jarak sebenarnya dari pintu masuk menuju air terjun? Tuliskan langkah penyelesaiannya!

(Sumber: Soal USBN SD/MI tahun ajaran 2018/2019)

Soal nomor 31 merupakan soal essay pada soal USBN SD/MI tahun ajaran 2018/2019. Soal ini memuat indikator kemampuan komunikasi matematis yaitu:

Tabel 1. Identifikasi Soal Nomor 31

\begin{tabular}{ll}
\hline $\begin{array}{c}\text { Indikator kemampuan komunikasi } \\
\text { matematis }\end{array}$ & \multicolumn{1}{c}{ Penyelesaian } \\
\hline merumuskan informasi & Diketahui: \\
& Jarak pada gambar $(\mathrm{Jg})=6 \mathrm{~cm}$ \\
& Skala (s) $=1: 25.000$ \\
menentukan strategi penyelesaian & Ditanya: Jarak sebenarnya dari pintu masuk sampai ke air terjun (Js)?
\end{tabular}




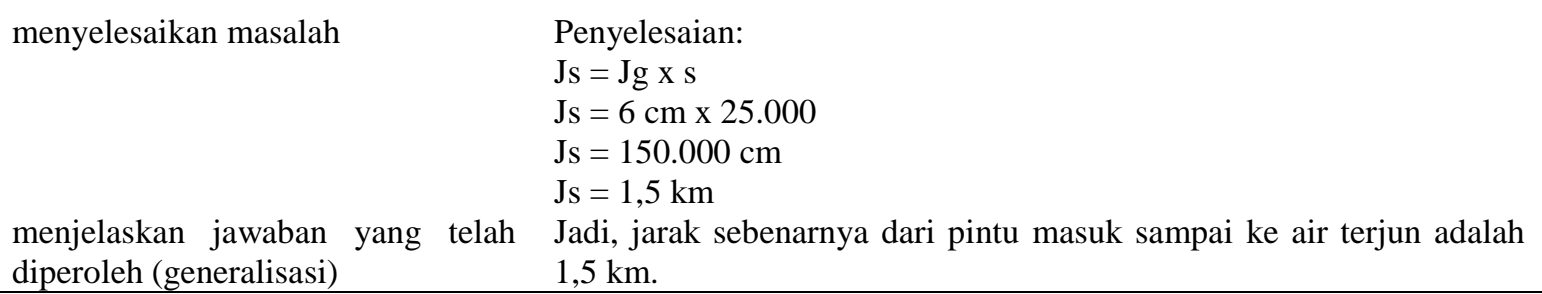

Dari tabel di atas, dapat dilihat bahwa soal nomor 31 mencakup indikator kemampuan komunikasi matematis. Pada soal ini, siswa dituntut untuk menyelesaikan soal dengan langkah-langkah yang sesuai dengan indikator kemampuan komunikasi matematis, dimana siswa merumuskan informasi dari soal yang ada bahwa diketahui jarak pada gambar dan skala. Setelah diketahui informasi soal siswa dapat menentukan strategi penyelesaian soal tersebut, yaitu menentukan apa yang ditanyakan. Setelah siswa mengetahui strategi apa yang akan digunakan, siswa menyelesaikan bagaimana mencari jarak sesungguhnya jika diketahui jarak pada peta dan skalanya. Setelah memperoleh penyelesaiannya siswa menjelaskan jawaban yang telah diperoleh (generalisasi).

Soal nomor 32

32. Tina, Siti, dan Ratna mengunjungi taman bacaan Mekar. Tina mengunjungi setiap 4 hari, Siti setiap 5 hari, dan Ratna setiap 6 hari. Tanggal 23 Februari 2019 , mereka bertiga mengunjungi taman bacaan bersama-sama untuk pertama kalinya. Mereka bertiga bersepakat kunjungan bersama yang kedua dimajukan 15 hari dari yang seharusnya. Pada tanggal berapakah mereka bertiga mengunjungi taman bacaan bersama untuk kedua kalinya?

(Sumber: Soal USBN SD/MI tahun ajaran 2018/2019)

Soal nomor 32 merupakan soal essay pada soal USBN SD/MI tahun ajaran 2018/2019. Soal ini memuat indikator kemampuan komunikasi matematis yaitu:

Tabel 2.Identifikasi Soal Nomor 32

\begin{tabular}{|c|c|}
\hline $\begin{array}{l}\text { Indikator kemampuan } \\
\text { komunikasi matematis }\end{array}$ & Penyelesaian \\
\hline merumuskan informasi & $\begin{array}{l}\text { Diketahui: Tina }=4 \text { hari, Siti }=5 \text { hari, Ratna }=6 \text { hari } \\
\text { Pertama kali bertemu bersama tgl } 23 \text { februari } 2019 \\
\text { Akan diajukan } 15 \text { hari untuk kedua kalinya bertemu. }\end{array}$ \\
\hline menentukan & Ditanya: \\
\hline penyelesaian & $\begin{array}{l}\text { Tanggal berapa mereka bertika bertemu bersama untuk kedua } \\
\text { kalinya? }\end{array}$ \\
\hline menyelesaikan masalah & Penyelesaian: \\
\hline
\end{tabular}




$$
\begin{aligned}
& \begin{array}{l}
4=2^{2} \\
5=5
\end{array} \\
& \begin{aligned}
& 6=2 \times 3 \\
& K P K=2^{2} \times 3 \times 5 \\
&=4 \times 3 \times 5 \\
&=60
\end{aligned}
\end{aligned}
$$

karena pertemuan mereka diajukan 15 hari maka:

$$
60-15=45 \text { hari }
$$

menjelaskan jawaban yang Jadi, mereka akan bertemu untuk kedua kalinya 45 hari setelah telah diperoleh (generalisasi) tanggal 23 februari 2019 yaitu tanggal 09 april 2019.

Dari tabel di atas, dapat dilihat bahwa soal nomor 32 mencakup indikator kemampuan komunikasi matematis. Pada soal ini, siswa dituntut untuk menyelesaikan soal dengan langkah-langkah yang sesuai dengan indikator kemampuan komunikasi matematis, dimana siswa merumuskan informasi yang didapat, yaitu waktu mengunjungi taman bacaan oleh Tina, Siti dan Ratna, juga tanggal di mana mereka pertama kali bertemu di taman bacaan secara bersamaan. Setelah itu siswa menentukan strategi penyelesaian, yaitu menentukan tanggal di mana mereka akan bertemu kedua kalinya di taman bacaan 15 hari lebih awal dari yang seharusnya. Setelah menentukan strategi, siswa menyelesaikan masalah dengan apa yang telah diketahui. Setelah siswa memperoleh jawabannya, siswa menjelaskan jawaban kapan Tina, Siti dan Ratna bertemu di taman bacaan untuk kedua kalinya setelah diajukan 15 hari dari tanggal yang seharusnya.

Soal nomor 33

33. Berat truk, sopir, kernet, beserta muatannya 3,56 ton. Truk tersebut mengangkut gula jawa 25 kemasan, bawang putih 30 karung, dan 15 karung bawang merah. Berat truk tanpa muatan 22 kuintal, sopir $71 \mathrm{~kg}$, dan kernet $64 \mathrm{~kg}$. Berat setiap kemasan gula jawa $10 \mathrm{~kg}$ dan setiap karung bawang putih $10 \mathrm{~kg}$. Jika berat tiap karung bawang merah sama, berapa berat tiap karung bawang merah?

(Sumber: Soal USBN SD/MI tahun ajaran 2018/2019)

Soal nomor 33 merupakan soal essay pada soal USBN SD/MI tahun ajaran 2018/2019.

Soal ini memuat indikator kemampuan komunikasi matematis yaitu:

Tabel 3.Identifikasi Soal Nomor 33

\begin{tabular}{cl}
\hline $\begin{array}{c}\text { Indikator kemampuan } \\
\text { komunikasi matematis }\end{array}$ & \multicolumn{1}{c}{ Penyelesaian } \\
\hline merumuskan informasi & Diketahui: \\
& Berat total $=3,56$ ton, Gula jawa $=25$ kemasan, Bawang putih $=$ \\
& $30 \mathrm{karung}$, Bawang merah $=15 \mathrm{karung}$ bawang merah, truk \\
& tanpa muatan $=22 \mathrm{kuintal}$, sopir $=71 \mathrm{~kg}$, kernet $=64 \mathrm{~kg}$. \\
& Berat setiap kemasan gula jawa $=10 \mathrm{~kg}$ \\
& Berat setiap karung bawang putih $=10 \mathrm{~kg}$
\end{tabular}




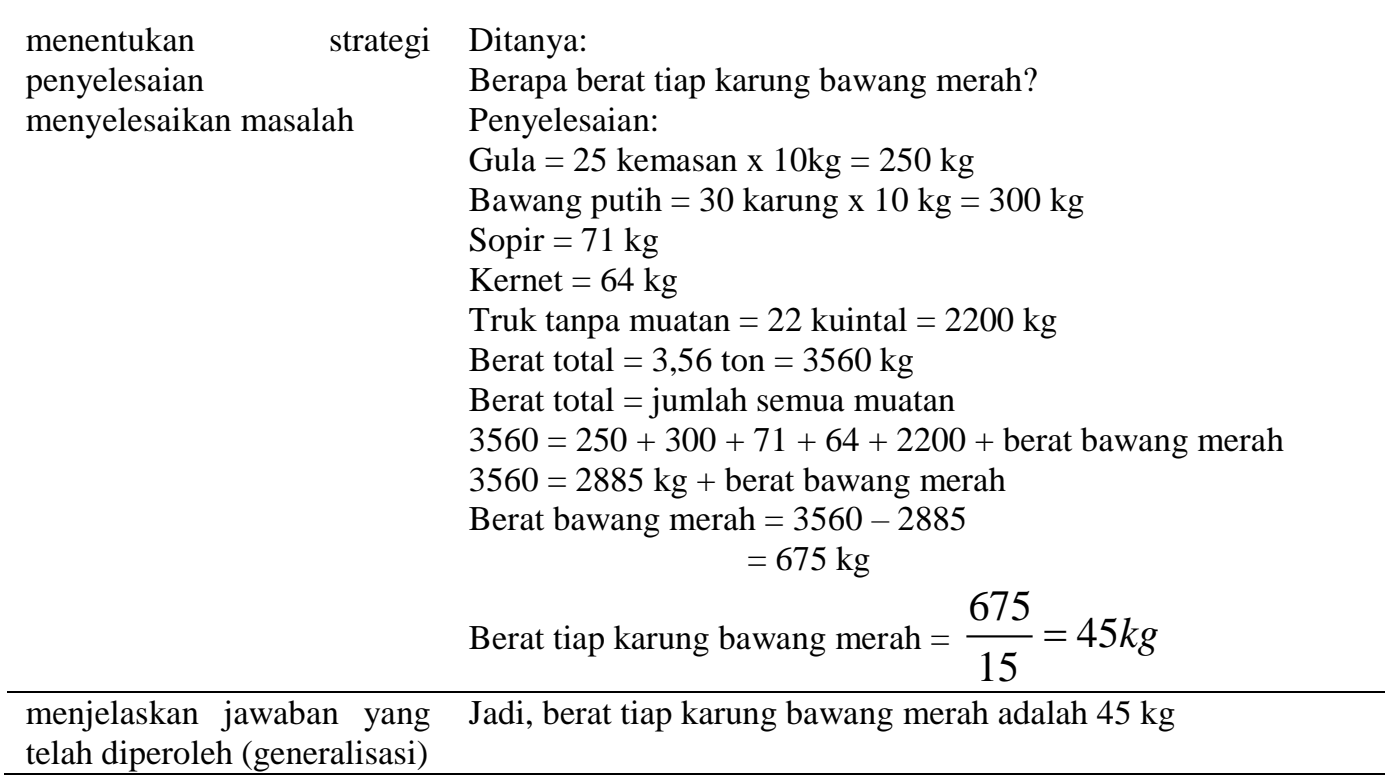

Dari tabel di atas, dapat dilihat bahwa soal nomor 33 mencakup indikator kemampuan komunikasi matematis. Pada soal ini, siswa dituntut untuk menyelesaikan soal dengan langkah-langkah yang sesuai dengan indikator kemampuan komunikasi matematis, dimana siswa merumuskan informasi bahwa diketahui berat total truk beserta muatan dan berat masing-masing muatannya. Setelah itu siswa menentukan strategi untuk mencari berat salah satu muatan truk tersebut. Setelah menentukan strategi, siswa menyelesaikan masalah sesuai informasi yang diperoleh. Setelah memperoleh penyelesaian, siswa menjelaskan jawaban dari penyelesaian.

\section{Soal nomor 34}

34. Pekarangan Pak Kasto berbentuk persegi panjang. Panjang pekarangan dua kali lebarnya. Pada kedua sisi panjang pekarangan ditanami pohon ketela. Setiap pohon ketela ditanam di dalam pekarangan dengan jarak $1 \mathrm{~m}$ dari tepi pekarangan. Jarak antar pohon $1,5 \mathrm{~m}$. Banyak pohon ketela ada 50 batang. Berapa meterkah keliling pekarangan Pak Kasto?

(Sumber: Soal USBN SD/MI tahun ajaran 2018/2019)

Soal nomor 34 merupakan soal essay pada soal USBN SD/MI tahun ajaran 2018/2019.

Soal ini memuat indikator kemampuan komunikasi matematis yaitu:

Tabel 4.Identifikasi Soal Nomor 34

\begin{tabular}{|c|c|}
\hline $\begin{array}{l}\text { Indikator kemampuan } \\
\text { komunikasi matematis }\end{array}$ & Penyelesaian \\
\hline \multirow[t]{5}{*}{ merumuskan informasi } & Diketahui: \\
\hline & Panjang pekarangan $=2 \times$ lebar pekarangan \\
\hline & Jarak antara pekarangan dan pohon $=1$ meter \\
\hline & Jarak antar pohon $=1,5$ meter \\
\hline & Banyak pohon ketela $=50$ batang \\
\hline menentukan & Ditanya: \\
\hline penyelesaian & Berapa meter keliling pekarangan Pak Kasto? \\
\hline menyelesaikan masalah & Penyelesaian: \\
\hline
\end{tabular}




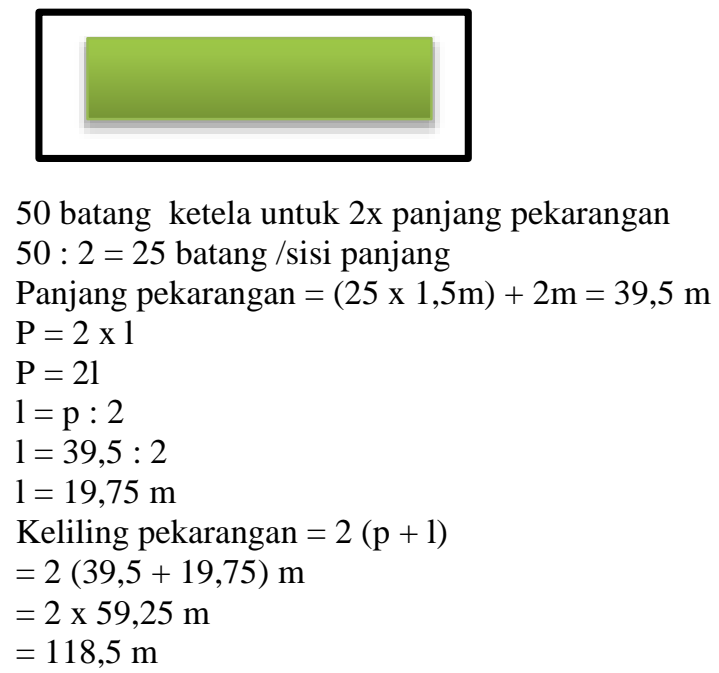

menjelaskan jawaban yang Jadi keliling pekarangan Pak Kasto adalah 118,5 meter. telah diperoleh (generalisasi)

Dari tabel di atas, dapat dilihat bahwa soal nomor 34 mencakup indikator kemampuan komunikasi matematis. Pada soal ini, siswa dituntut untuk menyelesaikan soal dengan langkah-langkah yang sesuai dengan indikator kemampuan komunikasi matematis, dimana siswa merumuskan informasi dari soal, yaitu Panjang pekarangan, jarak pekarangan dengan pohon, jarak antar pohonm dan banyak pohon ketela. Setelah mendapatkan informasi, siswa menentukan strategi untuk mencari keliling pekaranagn. Setelah mengetahui apa yang akan diselesaikan, siswa menyelesaikan masalah sesuai apa yang sudah diketahui. Setelah memperoleh penyelesaiannya, siswa dapat menjelaskan keliling pekarangan.

Soal nomor 35

\section{Rata-rata nilai matematika dari 18 siswa adalah 75 . Nilai tersebut belum termasuk nilai Fani dan nilai Firman. Setelah nilai Fani ditambahkan, rata-rata nilai menjadi 76. Nilai Fani 10 lebihnya dari nilai Firman. Berapakah nilai rata- rata matematika setelah nilai Firman ditambahkan?}

(Sumber: Soal USBN SD/MI tahun ajaran 2018/2019)

Soal nomor 35 merupakan soal essay pada soal USBN SD/MI tahun ajaran 2018/2019.

Soal ini memuat indikator kemampuan komunikasi matematis yaitu:

Tabel 5.Identifikasi Soal Nomor 35

\begin{tabular}{|c|c|}
\hline $\begin{array}{l}\text { Indikator kemampuan } \\
\text { komunikasi matematis }\end{array}$ & Penyelesaian \\
\hline merumuskan informasi & $\begin{array}{l}\text { Diketahui: } \\
\text { Rata-rata nilai } 18 \text { siswa kecuali Fani dan Firman }=75 \\
\text { Rata-rata nilai setelah ditambah nilai Fani }=76 \\
\text { Nilai fani } 10 \text { lebihnya nilai Firman }\end{array}$ \\
\hline menentukan & Ditanya: \\
\hline $\begin{array}{l}\text { penyelesaian } \\
\text { menyelesaikan masalah }\end{array}$ & $\begin{array}{l}\text { Berapa nilai rata-rata matematika setelah Firman ditambahkan? } \\
\text { Penyelesaian: } \\
18 \text { siswa } \times 75=1350\end{array}$ \\
\hline
\end{tabular}




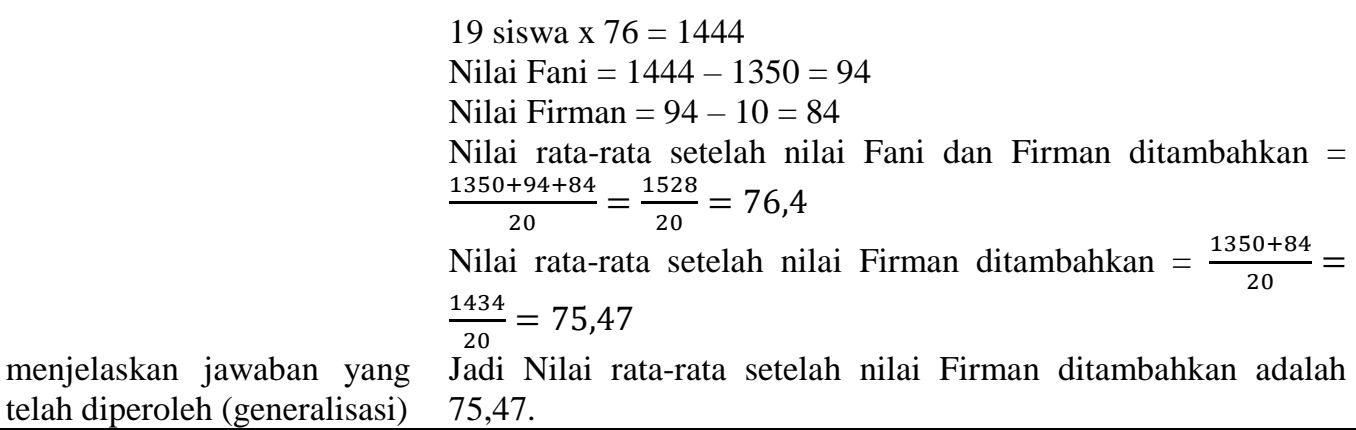

Dari tabel di atas, dapat dilihat bahwa soal nomor 35 mencakup indikator kemampuan komunikasi matematis. Pada soal ini, siswa dituntut untuk menyelesaikan soal dengan langkah-langkah yang sesuai dengan indikator kemampuan komunikasi matematis, dimana siswa merumuskan informasi bahwa diketahui nilai rata-rata 18 siswa, nilai rata-rata 19 siswa, dan nilai salah satu siswa. Setelah merumuskan informasi, siswa menentukan strategi berapa nilai rata-rata setelah ditambahkan dengan nilai seorang siswa yang lain. Setelah mengetahui strategi yang akan diselesaikan, siswa menyelesaikan masalah. Setelah memperoleh penyelesaian, siswa menjelaskan jawaban yang telah diperoleh (generalisasi).

\section{KESIMPULAN}

Pada soal Ujian Sekolah Berstandar Nasional Matematika SD/MI Tahun Ajaran 2018/2019 terdapat 35 soal, di mana 30 soal merupakan soal pilihan ganda dan 5 soal merupakan soal essay. Dari 35 soal USBN SD/MI Tahun ajaran 2018/2019 terdapat 5 soal yang memuat indikator kemampuan komunikasi matematis yaitu soal essay nomor $31,32,33,34,35$. Soal tersebut memuat indikator kemampuan komunikasi matematis secara lengkap dari merumuskan informasi, menentukan strategi penyelesaian, menyelesaikan masalah, menjelaskan jawaban yang telah diperoleh (generalisasi). Kemampuan komunikasi matematis siswa hanya kita temukan pada soal essay karena pada soal pilihan ganda siswa hanya sampai pada menemukan hasil atau menyelesaikan masalah, atau dengan kata lain siswa belum sampai kepada menggeneralisasi atau menjelaskan hasil yang telah diperoleh.

\section{DAFTAR PUSTAKA}

Anita, I. W. (2014). PENGARUH KECEMASAN MATEMATIKA (MATHEMATICS ANXIETY) TERHADAP KEMAMPUAN KONEKSI MATEMATIKA SISWA SMP. Bandung: Jurnal Ilmiah Program Studi Matematika (Invinity).

Hodiyanto. (2017). KEMAMPUAN KOMUNIKASI MATEMATIS DALAM PEMBELAJARAN MATEMATIKA. Pontianak: AdMathEdu.

Karunia Eka Lestari, M., \& Mokhammad Ridwan Yudhanegara, M. (2017). Penelitian Pendidikan Matematika. Bandung: PT Refika Aditama.

Rahmawati, F. (2013). Pengaruh Pendekatan Pendidikan Realistik Matematika dalam Meningkatkan Kemampuan Komunikasi Matematis Siswa Sekolah Dasar. Lampung: Fakultas MIPA Universitas Lampung. 
SELT $\Delta$ Jurnal Ilmiah Pendidikan Matematika

Sriwijayanti, P. (2018). Identifikasi Aspek Kemampuan Berfikir Kreatif Pada Soal Matematika Buku Tematik Terpadu Kurikulum 2013 Kelas IV Tema 9. Yogyakarta: Jurnal Math Education Nusantara, 1-9.

Umar, W. (2012). Membangun Kemampuan Komunikasi Matematis dalam Pembelajaran Matematika. Bandung: Jurnal Ilmu Program Studi Matematika (Invinity). 